\title{
Pola Komunikasi Ustaz Dan Santri Dalam Proses Pembelajaran Kitab Bulughul Maram Materi Tentang Silaturahmi Di Pondok Pesantren Nurul Falah Air Mesu
}

\author{
Fatimah $^{1}$, Nasrun ${ }^{2}$, Anna Musyarofah ${ }^{3}$
}

1IAIN Syaikh Abdurrahman Siddik

2IAIN Syaikh Abdurrahman Siddik

3IAIN Syaikh Abdurrahman Siddik

\begin{tabular}{l}
\hline \hline Info Artikel : \\
\hline Diterima 3 Januari 2020 \\
Direvisi 12 Januari 2020 \\
publikasikan 22 Januari2020
\end{tabular}

\section{Kata Kunci:}

Komunikasi pembelajaran, Ustaz

Komunikasi pembelajaran Santri,

Kitab Bulughul Maram

\section{eywords:}

Learning communication,

Ustaz

Communication Santri

learning,

The Book of Bulughul Maram

\begin{abstract}
ABSTRAK
Tujuan penelitian ini adalah 1) Untuk mengetahui bagaimana pola komunikasi ustaz dalam perencanaan pembelajaran kitab bulughul maram materi tentang silaturrahmi di Pondok Pesantren Nurul Falah Air Mesu Timur. 2) Untuk mengetahui faktor apa saja yang mempengaruhi pola komunikasi ustaz dan santri dalam proses pembelajaran kitab bulughul maram materi tentang silaturrahmi di Pondok Pesantren Nurul Falah Air Mesu Timur. Penelitian ini menggunakan jenis penelitian deskriptif kualitatif, yaitu melalui sumber data primer dan sumber data sekunder. Metode pengumpulan datanya dengan observasi, dokumntasi, wawancara. Teknis analisisnya dengan reduksi data, penyajian data dan menarik kesimpulan. Dari penelitian ini dapat dianalisis bahwa belajar kitab bulughul maram tergantung pembawaan seorang ustaz, semakin luas pengetahuan ustaz semakin mudah ia memberikan pengajaran. Hasilnya adalah komunikasi yang digunakan adalah lansung. Dalam proses pembelajaran pada hakikatnya merupakan proses komunikasi, yaitu proses penyampaian pesan dari komunikator (guru) kepada komunikan (siswa) dengan menggunakan saluran media tertentu. Tanpa komunikasi maka tidak akan tercapai secara maksimal dalam mendapatkan sebuah hasil yang diinginkan
\end{abstract}

\section{ABSTRACT}

The purpose of this study are 1) To find out how the pattern of Ustad communication in planning learning Bulughul Maram material about silaturrahmi in Nurul Falah Islamic Boarding School Mesu Timur. 2) To find out what factors influence the pattern of ustaz and santri communication in the process of learning Bulughul Maram material about silaturrahmi at Nurul Falah Islamic Boarding School, Mesu Timur. This research uses descriptive qualitative research, namely through primary data sources and secondary data sources. The method of data collection is by observation, documentation, interview. Technical analysis with data reduction, data presentation and drawing conclusions. From this research it can be analyzed that studying bulughul maram depends on the carrying of an ustaz, the broader the knowledge of the ustaz the easier it is to give teaching. The result is the communication used is direct. In the learning process is essentially a communication process, namely the process of delivering messages from the communicator (teacher) to the communicant (students) using certain media channels. Without communication it will not be achieved optimally in getting a desired result

Koresponden:(9 pt)

Fatimah

Email: fatimahrazaq@gmail.com 


\section{PENDAHULUAN}

Komunikasi adalah salah satu perilaku manusia yang sering digunakan dalam sehari-hari. Komunikasi juga dapat dilakukan dimana saja, oleh siapa saja dan kapan pun komunikasi tersebut diperlukan. Komunikasi merupakan bagian penting dalam kehidupan sehari-hari. Begitu pentingnya komunikasi itu bagi manusia, tanpa komunikasi manusia tidak dapat bertahan hidup. Komunikasi dalam pendidikan dan pengajaran berfungsi sebagai pengalihan ilmu pengetahuan yang mendorong perkembangan intelektual, pembentukan watak dan keterampilan serta kemahiran yang diperlukan pada semua bidang kehidupan.

Fungsi komunikasi tidak hanya sebagai pertukaran informasi dan pesan, tetapi sebagai kegiatan individu dan kelompok mengenai tukar menukar data, fakta dan ide. Agar komunikasi berlangsung efektif dan informasi yang disampaikan oleh seorang pendidik dapat diterima dan dipahami oleh peserta didik dengan baik, maka seorang pendidik perlu menerapkan komunikasi yang baik pula. ${ }^{1}$

Pondok Pesantren Nurul Falah adalah suatu lembaga pendidikan pembelajaran yang mengkhususkan ilmu agama, pesantren ini juga menerapkan pembelajaran kitab Bulughul Maram, di dalam kitab tersebut terdapat materi tentang silaturahmi. Kitab Bulughul Maram adalah kitab hadits yang ringkas di dalamnya termuat hukum-hukum fiqih. Kitab ini pada dasarnya ditunjukan sebagai tuntutan praktis dalam kehidupan umat islam sehari-hari. Kitab ini juga termasuk kitab fikih yang menerima pengakuan global dan juga banyak diterjemahkan di seluruh dunia. Kitab Bulughul Maram memiliki keutamaan yang istimewa karena seluruh hadits yang termuat didalamnya menjadi pondasi landasan fikih dalam Mazhab Syafi'i. ${ }^{2}$

Dalam materi silaturahmi ini diharapkan dapat memperbaiki pola komunikasi antara Ustaz dan Santri dalam proses pembelajaran. Karena biasanya penyampaian Ustaz dalam menyampaikan materi dalam kitab Bulughul Maram kurang menarik dan monoton sehingga para santri merasa jenuh ketika proses pembelajaran berlangsung. Oleh karena itu ustaz dan pesantren adalah merupakan elemen yang sangat penting dalam mengarahkan santri-santrinya. Di Pondok Pesantren Nurul Falah seorang ustaz sangat dekat dan lebih intens terhadap santrinya, hal ini banyak disadari seorang santri didalam pondok jauh lebih hormat dan taat kepada gurunya, santri di pondok pesantren akan dapat perhatian lebih dari figur sang guru (ustaz) mereka.

Pondok pesantren Nurul Falah Air Mesu Timur adalah suatu pesantren yang mempunyai perhatian terhadap pendidikan dalam mencapai kualitas santri yang dapat memahami pelajaran secara baik dan benar berdasarkan tata cara penyampaian yang dilakukan. Sebagaimana yang telah diuraikan di atas maka peneliti ingin mengkaji lebih mendalam tentang "Pola Komunikasi Ustaz dan Santri dalam Proses Pembelajaran Kitab Bulughul Maram Materi Tentang Silaturahmi di Pondok Pesantren Nurul Falah Air Mesu Timur".

\section{METODE}

Jenis penelitian yang digunakan dalam penelitian ini adalah jenis penelitian deskriptif kualitatif. Menurut Sugiono, penelitian kualitatif adalah penelitian yang memandang objek sebagai sesuatu yang dinamis, hasil konstruksi pemikiran dan interprestasi terhadap gejala yang diamati, serta utuh karena setiap aspek objek itu mempunyai satu kesatuan yang tidak dapat dipisahkan. ${ }^{3}$ Teknikpengumpulan datadata serta hasil penelitian yang akurat, penggunaan teknik pengumpulan data ini memungkinkan akan memperoleh data yang objektif. ${ }^{4}$ Untuk memperoleh data yang dibutuhkan dalam penelitian ini maka digunakan adalah, wawancara, observasi dan dokumentasi.

\section{HASIL DAN PEMBAHASAN}

A. Pola Komunikasi Ustaz dan Santri Dalam Proses Pembelajaran Kitab Bulughul Maram Materi Tentang Silaturahmi Di Pondok Pesantren Nurul Falah Air Mesu Timur. Berdasarkan hasil wawancara dan pengamatan yang telah dilakukan oleh penulis dijelaskan bahwa analisis data yang berkaitan dengan hasil penelitian, yaitu Pola Komunikasi Ustaz Dan Santri Dalam Proses Pembelajaran Kitab Bulughul Maram Materi Tentang Silaturahmi Di Pondok Pesantren Nurul Falah Air Mesu Timur. Dalam proses pembelajaran dengan fokus materi Silaturahmi, ustaz menggunakan pola komunikasi. Adapun menurut ustaz Iskandar mengungkapkan bahwa: "Komunikasi itu ialah suatu proses yang mana

\footnotetext{
${ }^{1}$ Asnawir dan Basyiruddin Usman, Media Pembelajaran, (Jakarta : Ciputat Press, 2002), hlm. 7.

2 Dzulmani, Mengenal Kitab-Kitab Hadits, (Yogyakarta: Pustaka Insan Madani, 2008), hlm. 187.

${ }^{3}$ Sugiono, Metode Penelitian, (Pendekatan Kuantitatif, Kualitatif, dan R \& D), (Bandung: Alfabet, 2015), hlm. 17.

${ }^{4}$ Margono, Metodologi Penelitian Pendidikan, (Jakarta: Rineka Cipta, 2005), hlm. 158.
} 
seseorang ataupun beberapa orang, kelompok yang menciptakan dan menggunakan informasi agar bisa terhubung dengan lingkungan dan orang lain." ${ }^{5}$

Peneliti menganalisis bahwa pola komunikasi merupakan proses penyampaian pesan untuk seseorang ataupun perkelompok, yang menciptakan informasi agar bisa terhubung dengan lingkungan. Dalam pola komunikasi ustaz menggunakan beberapa media atau alat peraga dalam menunjang proses pembelajaran. Materi yang ustaz sampaikan adalah materi silaturahmi yang terdapat pada kitab bulughul maram.

Kitab bulughul maram adalah kitab hadits yang ringkas di dalamnya termuat hukum-hukum fiqih. Kitab ini pada dasarnya ditunjukan sebagai tuntutan praktis dalam kehidupan umat islam sehari-hari. Kitab ini juga termasuk kitab fikih yang menerima pengakuan global dan juga banyak diterjemahkan di seluruh dunia. Kitab Bulughul Maram memiliki keutamaan yang istimewa karena seluruh hadits yang termuat didalamnya menjadi pondasi landasan fikih dalam Mazhab Syafi'i. ${ }^{6}$ Adapun menurut ustaz Iskandar, beliau mengungkapkan bahwa:"Menurut saya kitab bulughul maram adalah kitab yang mengkaji hadist dan fiqih yaitu rujukan yang sederhana yaitu kitab bulughul maram. Sangat bagus dan sangat cocok untuk dipelajari dikalangan santri dan santriwati karena dalil-dalil hukum kehidupan kita sehari-hari, seperti yang tertera dalam materi silaturrahmi. Dan bentuk menariknya di bulughul maram itu pada bab pelengkap yang terakhir, disitu harus dihapalkan oleh setiap santri."7Peneliti menganalisis bahwa kitab bulughul maram merupakan kitab hadist tematik yang memuat hadits-hadits yang dijadikan sumber pengambilan hukum fiqih oleh para ahli fiqih. Kitab ini menjadi rujukan utama khususnya bagi fiqih dari mazhab syafi'i. Dalam proses pembelajaran kitab bulughul maram materi tentang silaturrahmi ustaz menggunakan beberapa jenis pola komunikasi antara lain:

1. Komunikasi Intrapersonal

Komunikasi intrapersonal ini juga merupakan keterlibatan intral secara aktif dari individu dalam proses dari pesan-pesan tersebut. Seseorang individu menjadi pengirim ataupun sekaligus penerima pesan, yang memberikan umpan balik bagi dirinya sendiri didalam proses internal yang berkelanjutan. Komunikasi intrapersonal ini juga cenderung untuk melihat kemampuan setiap santrinya dan memberikan motivasi terhadap santri yang memang mengalami kesulitan dalam proses pembelajaran.

Adapun komunikasi intrapersonal ditentukan oleh kemampuan seorang supaya mengkomunikasikan secara jelas apa yang ingin disampaikan, menciptakan kesan yang diinginkan, atau mempengaruhi orang lain sesuai kehendak kita. Kita juga dapat meningkatkan keefektifan dalam hubungan antar pribadi sebagai cara berlatih mengungkapkan apa yang diinginkan., menerima umpan balik tentang tingkah laku, dan memodifikasikan tingkah laku kita sampai orang lain mempersepsikannya sebagaimana yang dimaksudkan artinya, sampai akibat-akibat yang akan ditimbulkan oleh tingkah laku kita dalam diri orang lain itu seperti yang dimaksudkan. ${ }^{8}$

Disini penulis mengambil pola komunikasi intrapersonal karena disini, seorang ustaz melakukan cara pendekatan diri kepada santrinya sebagaimana kedekatan orang tua dengan anak. Akan tetapi seorang santri tidaklah mulus dalam pembelajaran kitab bulughul maram ini, karena seorang santri mempunyai hambatan sebagai berikut: "Yang pertama dari pola bahasa karena ustaz mengajar bukan memakai buku yang terjemahan, dan terkendala santri tidak paham arti dari hadist tersebut. Yang kedua karena anak yang begronnya dari SMP sebab itulah mereka tidak paham karena baru mengenal arab gundul sehingga dimana ustaz yang seharusnya menyampaikan 10 atau 15 hadist dalam semalam yang harus dijelaskan tetapi kenyataannya tidak mencapai target. Dan hambatan yang ketiga para santri tersebut kurang berminat untuk mempunyai kitab bulughul maram tersebut". 9

Dalam mempelajari kitab bulughul maram ini juga harus memerlukan tingkat kesabaran yang tinggi bagi para pengajarnya yang mana juga harus memiliki pengetahuan luas, begitu juga dengan sikap sangatlah diperlukan untuk pengjar kitab bulughul maram. Karena sikap sabar sangatlah diperlukan dalam pengajaran dalam menghadapi santri yang lama dalam pemahaman. Pola komunikasi yang berlangsung antara ustaz dan santri dalam penyampaian kitab bulughul maram, ustaz kepada santrinya itu tidak terburu-buru dan menggunakan sistem audioturial (berdiri dan mendengarkan). Cara ustaz memberikan komunikasi tentang pembelajaran kitab bulughul maram biasanya lebih sering menggunakan cara lisan kepada santrinya. Disamping itu, santri dapat berkomunikasi dengan ustaz di luar kelas jika ada yang kurang dipahami atau tidak dimengerti oleh santrinya. Selain berkomunikasi dengan ustaz di luar kelas, santri juga dapat berkomunikasi dengan sesama santri lainnya tentang pelajaran yang telah diberikan ustaz untuk didiskusikan bersama. "Komunikasi yang digunakan dalam

\footnotetext{
5Wawancara langsung dengan Ustaz Iskandar, Tanggal 6 November 2019, di Pesantren Nurul Falah Air Mesu Timur. ${ }^{6}$ Dzulmani, Mengenal Kitab-Kitab Hadits, (Yogyakarta: Pustaka Insan Madani, 2008), hlm. 187.

${ }^{7}$ Wawancara langsung dengan Ustaz Iskandar, Tanggal 6 November 2019, di Pesantren Nurul Falah Air Mesu Timur.

8 Dr. A. Supratiknya, Komunikasi Antarpribadi Tinjauan Psikologis, (Yogyakarta: Kanisius, 1995) hlm. 24.

${ }^{9}$ Wawancara langsung dengan Ustaz Iskandar, Tanggal 6 November 2019, di Pesantren Nurul Falah Air Mesu Timur.
} 
keseharian di Pondok Pesantren Nurul Falah Air Mesu Timur ialah menggunakan bahasa Indonesia, Arab dan Inggris". 10

Personaliti kelompok merupakan sekelompok orang yang datang bersama mereka untuk membuat identitas mereka sendiri yang menjadikan personaliti kelompok. Kekompakan yang mana daya tarik anggota kelompok satu sama lain dan keinginan mereka untuk bersatu. Komitmen terhadap tugas, besarnya kelompok kelihatannya cukup sederhana tetapi besarnya kelompok itu mempunyai beberapa pencabangan penting dalam kelompok. ${ }^{11}$

Komunikasi interpersonal adalah suatu kumpulan individu yang dapat mempengaruhi satu sma lain, yang dapat memperoleh beberapa kepuasan satu sama lain, yang mana berinteraksi untuk bertujuan mengambil peranan, terikat satu sama lain dan berkomunikasi saling tatap muka. Begitu juga ustaz Iskandar mengungkapkan bahwa:

"Proses belajar mengajar di pondok pesantren Nurul Falah ini dapat terjadi disaat seorang ustaz menyampaikan materi kepada para santrinya didalam sebuah pelaksanaan program pembelajaran. Program-program ini biasanya dilakukan didalam ruangan, dan masa yang berada didalam ruangan tersebut bisa dikatakan sebagai komunikasi interpersonal. Dimana komunikasi interpersonal ini merupakan komunikasi yang terjadi antara dua orang atau lebih, yang biasanya tidak diatur secara formal".12

Peneliti dapat menyimpulkan bahwa komunikasi interpersonal ini, para santri memang mengikuti pembelajaran kitab bulughul maram yang dilakukan pada waktu setelah shalat isya. Komunikasi ini berdasarkan semua interaksi manusia untuk berkomunikasi. Manusia sebagai makhluk sosial yang senantiasa memerlukan orang lain untuk bekerja sama dalam mencapai tujuannya, sehingga dijumpai orang-orang yang disebut kelompok. Kelompok kecil mempunyai batasan yang ditinjau dari jumlah anggotanya yang sangat tergolong kecil, namun tidak adanya batasan berapa jumlah orang yang ada didalamnya. Asalkan dalam kelompok kecil tersebut harus ada hubungan/komunikasi.

Komunikasi interpersonal, komunikator menunjukan pesannya kepada benak atau pikiran komunikan seperti dalam pengajaran kitab bulughul maram. Oleh sebab itu logika sangatlah berperan penting dan komunikan akan mendapatkan masukan dari uraian yang diberikan komunikator. Komunikasi interpersonal prosesnya berlangsung secara dialogis, umpan balik (feed back) terjadi secara verbal, dan komunikan juga dapat menanggapi apa yang disampaikan komunikator, adapun komunikan bisa bertanya, menyanggah atau berpendapat.Seorang santri belajar dengan system musyawarah (kumpul) disuatu tempat yang dinamakan aula dan juga ada kelas yang tersedia dimana mereka melakukan pembelajaran kitab bulughul maram dari mulai setelah isya. Tetapi di pondok pesantren Nurul Falah Air Mesu Timur ini para santri belajar di Masjid.

Setiap proses pembelajaran akan mencapai tingkat keberhasilan yang maksimal bila didukung dengan hubungan komunikasi yang baik antara ustaz dan santri. Pesantren ialah lembaga pendidikan yang mayoritasnya memberikan ilmu agama yang secara mendalam. Pola pengajaran yang dilaksanakan dalam program pembelajaran kitab bulughul maram di pondok pesantren ini ialah suatu proses pemberiaan materi kepada para santri yang secara keseluruhan atau secara bersama-bersama mendengarkan ketika ustaz membaca, menterjemahkan, menerangkan, dan mengupas secara mendalam pada materi yang berbahasa arab tersebut. Iskandar mengungkapkan bahwa dalam penyampaian materi:

"Seperti halnya memberikan referensi-referensi tambahan agar materi yang disampaikan itu lebih berisi dan berbobot. Karena ketika kita melakukan cara penyampaian secara khusus, biasanya akan terbawa pada suasana pengajian yang kurang efektif. Dan juga memberikan kerugian pribadi pada diri saya sendiri maupun kerugian umum bagi para santri."13

Peneliti berpendapat bahwa, dalam pemberian materi ustaz menambahkan referensi-referensi dari luar buku untuk menambah referensi sehingga santri bisa memiliki banyak referensi untuk mencapai

\footnotetext{
10 Wawancara langsung dengan Ustaz Iskandar, Tanggal 6 November 2019, di Pesantren Nurul Falah Air Mesu Timur.

${ }^{11}$ Ami Muhammad, Komunikasi Organisasi, ( Jakarta: Bumi Aksara, 2011), hlm. 185-1886

12 Wawancara langsung dengan Ustaz Iskandar, Tanggal 6 November 2019, di Pesantren Nurul Falah Air Mesu Timur.

13Wawancara langsung dengan Ustaz Iskandar, Tanggal 6 November 2019, di Pesantren Nurul Falah Air Mesu Timur.
} 
pembelajaran yang optimal. Para ustaz memiliki penyampaian secara khusus, ada beberapa kendala yang ustaz alami dalam penyampian tetapi ada jalan keluar dalam kendala yang ustaz hadapi.

Pola komunikasi yang dilakukan dalam program ini ialah dengan menggunakan komunikasi kelompok kecil yang dilakukan adalah menggunakan metode ceramah, yang mana ustaz bertatap muka dengan sejumlah santri secara langsung dan membahas hadits demi hadits yang terdapat didalam kitab bulughul maram tersebut. Adapun Sangatlah cocok dengan komunikasi seperti itu, dikarenakan santri memang mengharapkan agar ustaz memberikan pengetahuan ilmu agamanya dengan kitab bulughul maram sebagai kajiannya.

Selain itu ustaz menggunakan pola komunikasi intruksional dengan memberi perintah kepada santri untuk menghafal hadits yang telah dibahas secara bersama-sama saat pelajaran berlangsung. Karena hal ini dapat menambah keilmuan santri dalam segi wawasan dan pengetahuan ilmu agama bagi diri mereka masing-masing.Di pesantren ada dua istilah yang terkait dengan cara-cara yang digunakan untuk menyampaikan ajaran sampai ketujuan. Mastuhu didalam bukunya menggunakan istilah motodik didaktik pengajaran, (yang mana didalam bukunya yang berjudul "Dinamika SistemPendidikan Pesantren) dan ada juga menurut departemen agama menggunakan istilah metode pembelajaran (pola pengembangan pondok pesantren) yang didalamnya menggunakan metode sorongan, wetonan, atau bendongan, metode halaqoh, hafalan, diskusi dan metode majlis taklim. Dalam penyampaian ustaz menambahkan pesan moral dalam penyampaian materi pembelajaran, Iskandar mengungkapkan bahwa:

"Pasti ada, karena dalam setiap hadits itu terdapat makna yang tersurat dan tersirat. Misalnya dalam materi tentang silaturahmi tersebut, kita ambil hikmah atau pesan-pesan moral dari hadits-hadits tersebut seperti, arti hadits yang berbunyi "tidak akan masuk surga seseorang yang memutuskan tali silaturrahmi" nah, hikmah dari arti hadist tersebut pasti ada." ${ }^{14}$

Dalam hal ini, peneliti menganalisis bahwa dalam penyampaian materi ustaz menyelipkan pesan moral untuk para santri. Dengan adanya materi tentang silaturahmi ini ustaz mengajak santri untuk saling menghargai sesama manusia dan menjaga tali komunikasi yang baik. Adapun timbal balik santri terhadap materi silaturahmi, menurut Iskandar, menggungkapkan bahwa:

"Ada, dengan adanya mereka sudah belajar dari materi tentang silaturrahmi tersebut, mereka yang selama ini hubungannya dengan kawan, orang tua yang kurang baik, setelah mereka belajar materi tersebut mereka sadar bahwa pentingnya arti ilmu yang telah mereka dapatkan."15

Peneliti dapat menyimpulkan bahwa dengan adanya pembelajaran materi yang disampaikan oleh ustaz tentang silaturrahmi membantu mereka saling menjaga hubungan dengan adanya komunikasi dan silaturahmi itu juga sangatlah penitng dalam sesama manusia. Dalam proses pembelajaran terdapat strategi, metode, dan media pembelajaran yang ustaz gunakan. Iskandar, menggungkapkan bahwa:

"Dengan cara memberikan pengajian melalui metode penjelasan dalam kitab bulughul maram yang diajarkan yang kemudian dilanjutkan dengan memberikan sebuah pertanyaan, agar para santri bisa merespon apa yang telah saya sampaikan." 16

Dengan demikian ustaz menggunakan beberapa metode dalam proses pembelajaran dengan materi silaturahmi. Ustaz menggunakan metode karena untuk membuat peserta didik aktif dalam hal bertanya atau pun menjawab dan juga adanya metode pembelajaran ustaz bisa mengarahkan para santri untuk mencapai pembelajaran yang optimal. Ada beberapa metode yang baik dalam pelaksanaan tentang materi silaturahmi. Metode yang dinamakan sorongan ialah suatu metode yang ditempuh dengan menggunakan cara guru menyampaikan pelajaran kepada sang santri secara individual dan umumnya diberikan kepada santri-santri baru yang masih perlu dibimbing. Dengan cara metode ini pula, ustaz dapat memberikan bimbingan yang penuh dengan kejiwaanya sehingga dapat memberikan tekanan pengajaran kepada santrisantrinya atas dasar observasi secara langsung terhadap tingkat kemampuan seorang santri. ${ }^{17}$

Metode wetonan atau bendongan, ialah suatu metode pengajaran dengan cara guru membaca, menerjemahkan dan mengulas kitab-kitab islam atau yang bisa di sebut kitab bulughul maram dalam

${ }^{14}$ Wawancara langsung dengan Ustaz Iskandar, Tanggal 6 November 2019, di Pesantren Nurul Falah Air Mesu Timur. 15Wawancara langsung dengan Ustaz Iskandar, Tanggal 6 November 2019, di Pesantren Nurul Falah Air Mesu Timur. ${ }^{16}$ Wawancara langsung dengan Ustaz Iskandar, Tanggal 6 November 2019, di Pesantren Nurul Falah Air Mesu Timur.

17 Qomar, Mujamil, Pesantren Dari Transformasi Metodologi Menuju Demokratisasi Intitusi, (Jakarta, Erlangga: tt), hlm. 143. 
bahasa arab sementara itu para santri mendengarnya. ${ }^{18}$ Santri memperhatikan kitabnya sendiri dan membuat catatan atau ringkasan (baik arti ataupun keterangan) tentang kata-kata yang sulit. Kelompok kelas dari metode bendongan ini disebut halaqoh ialah lingkaran sekelompok murid atau santri yang berada bibawah bimbingan seorang guru.

Metode hafalah (Tahfidz) yang merupakan sebuah metode pembelajaran yang mana pada umumnya diterapkan pada mata pelajaran yang bersifat nazham (Syair), yang biasanya terbatas pada ilmuilmu yang terkait pada kaidah-kaidah bahasa arab. Namun demikian, ada juga yang dihafal dalam bentuk prosa (natsar).Metode ini biasanya menggunakan dua cara. Pertama, pada setiap kali tatap muka para santri diwajibkan untuk membaca hafalannya didepan ustaz, jika sudah hafal maka diperbolehkan untuk melanjutkan kehafalan yang berikutnya.

Kedua, ustaz memerintahkan santrinya untuk mengucapkan bagian tertentu dari hafalannya yang telah ditugaskan, ataupun memerintahkan santrinya untuk melanjutkan kalimat atau lafadz yang telah ia ucapkan. ${ }^{19}$

Metode diskusi (musyawarah/munazharah/mudzakah) yang mana pada metode ini para santri akan membahas suatu topic atau masalah tertentu yang terdapat dalam kitab. Dalam permasalahan ini terdapat tukar menukar pendapat diantara mereka sementara ustaz atau santri senior bertindak sebagai mederator.Hal ini hampir sama dengan metode diskusi ialah metode mudzakarah yang merupakan suatu pertemuan ilmiah yang secara spesifik yang membahas masalah diniyah seperti aqidah, ibadah, dan masalah agama yang pada umumnya. Hanya bedanya mudzakarah diikuti oleh para ustaz atau para santri yang telah memiliki wawasan dan pengetahuan yang sangat mendalam. Biasanya metode diskusi atau musyawarah ini menggunakan bahasa arabdalam setiap penyampaian sehingga bisa menjadi ajang latihan keterampilan santri.

Metode majlis taklim ialah metode pembelajaran dengan cara berceramah, yang biasanya disampaikan dalam kegiatan tabligh atau kuliah umum. Didalam kegiatan ini bukan hanya santri yang mukim atau santri kalong saja yang sering mengikuti majlis taklim, akan tetapi juga masyarakat yang mengikuti kegiatan tersebut, dalam pengajian ini masyarakat sekitar bisa ikut dikarenakan majlis taklim ini bisa untuk umum sehingga bisa terjadinya hubungan silaturahmi antara santri dengan masyarakat.

Di samping itu metode-metode yang sering ditemukan didalam lapangan terkadang dalam proses pembelajaran kitab dapat juga dilakukan dengan proses metode penulisan karya ilmiah. Maka sekurangkurangnya dengan menulis resume atau ikhtiar tentang suatu topic yang ada didalam kitab bulughul maram. Penulisannya bisa juga menggunakan bahasa Arab dan bisa pula dengan bahasa Indonesia.

Maka pada kelima metode diatas yang telah diketahui pada prinsipnya digunakan oleh Pesantren Nurul Falah Air Mesu Timur. Yang dimana untuk metode sorongan didalam pengertiannya yang pertama. Adapun metode sorongan dalam pengertiannya yang pertama, biasanya diaplikasikan bagi santri yang berada pada tingkat persiapannya. Dimana santri-santri yang senior tanggung jawab untuk membimbing atau memantau perkembangannya. Iskandar, menggungkapkan bahwa:

"Dari metode-metode yang diatas dapat disimpulkan di pesantren sangatlah melekat nilai-nilai kebersamaan dan juga tidak ada seorang ustaz yang hanya bisa mengajar melalui kesadaran diri santri dan juga diharuskan belajar mengajar secara mandiri tetapi disini menjadi pengajar hanya santri yang lebih menguasai kemampuan didalam mata pelajaran yang bisa diberikan kepada santri". ${ }^{20}$

Peneliti menyimpulkan bahwa dengan adanya metode-metode dalam proses belajar mengajar sangatlah membantu ustaz dalam menyampaikan materi yang akan disampaikan kepada peserta didik. Media atau alat perga juga digunakan dalam proses pembelanjaran tentang materi silaturahmi dalam kitab Bulughul maram. Iskandar menyampaikan bahwa:

18 Zamakhsyari Dhofier, Tradisi Pesantren: Studi Tentang Pandangan Hidup Kyai, (Jakarta: LP3S, 1982), hlm. 68.

${ }^{19}$ Amin Haedari, dkk, Masa Depan Pesantren: Dalam Tantangan Modernitas dan Tantangan Kompleksitas Globa, ( Jakarta: IRD Press, 2004), hlm. 18.

${ }^{20}$ Wawancara langsung dengan Ustaz Iskandar, Tanggal 6 November 2019, di Pesantren Nurul Falah Air Mesu Timur. 
"Media yang saya gunakan pasti ada, seperti kitab bulughul maram itu sendiri, dan peralatan yang digunakan seperti infocus dan juga papan tulis sebagai ilustrasi dari materi yang saya sampaikan agar lebih mudah dipahami santri."21

Media sangatlah penting dalam proses pembelajaran karena media pembelajaran menjadi penunjang dalam proses pembelajaran. Dapat peneliti simpulkan bahwasannya ustaz mempunyai strategi, metode dan media pembelajaran dalam proses pembelajaran dengan materi silaturahmi dalam kitab Bulughul maram. Adanya 3 komponen tersebut membantu ustaz dalam mengoptimalkan proses pembelajaran dan membantu dalam mengajak para santri aktif dalam proses pembelajaran.

Dari hasil observasi terhadap proses pembelajaran kitab bulughul maram materi tentang silaturrahmi di pondok pesantren Nurul Falah Air Mesu Timur ini, proses belajar mengajar secara langsung. Ustaz membacakan kitab bulughul maram yang akan dibahas dan santri menyimak apa yang disampaikan ustaz. Adapun ustaz pengajar kitab bulughul maram tersebut memberikan kesempatan kepada santri untuk bertanya agar ustaz mengetahui apakah santrinya paham atau tidak dalam materi yang diajarkan. ${ }^{22}$

B. Manfaat-Manfaat Pola Komunikasi Ustaz dan Santri dalam Proses Pembelajaran kitab bulughul maram materi tentang silaturrahmi di pondok pesantren Nurul Falah Air Mesu Timur. Komunikasi merupakan aktivitas yang sangat penting didalam kehidupan ini. Komunikasi sendiri adalah proses atau interaksi yang dilakukan antar individu atau lebih guna mencapai kesepakatan hasil atau tujuan tertentu yang diinginkan bersama. Dengan melakukan komunikasi, kita akan tahu banyak hal seperti informasiinformasi yang sangat penting yang sangat berguna untuk berbagai keperluan.Adapun menurut Iskandar mengatakan bahwa:

"Manfaat komunikasi ialah untuk mengetahui, memahami semua informasi yang di perlukan, ada juga mempererat tali persaudaraan antar pribadi dan kelompok". ${ }^{23}$

Peneliti dapat menyimpulkan bahwa manfaat komunikasi antar ustaz dan santri itu sangatlah penting dalam proses belajar mengajar apalagi dalam materi Bulughul Maram tentang materi silaturahmi ini, dan juga membantu ustaz dan santri memudahkan dalam proses belajar mengajar. Tidak hanya manfaat, memotivasi siswa juga salah satu peran dari komunikasi.

Adapun menurut Iskandar menggungkapkan bahwa:

"Mayoritas santri mempunyai semangat belajar yang tinggi, namun masih ada juga santri yang motivasi belajarnya masih kurang/rendah sebab itulah bagi seorang ustaz harus bisa memotivasi kan santri-santri nya untuk belajar dengan baik dan benar." 24

Peneliti dapat menyimpulkan bahwa ustaz memberikan motivasi disetiap pembelajaran, dalam hal memotivasi sangat bermanfaat karena jika dalam pembelajaran tanpa motivasi, sangat mungkin pembelajaran tidak menghasilkan hasil yang lebih baik. Tidak hanya memotivasi tetapi didalam komunikasi juga terdapat penyajian informasi.

Menurut Iskandar, mengatakan bahwa:

"Dalam penyajian informasi ini saya, masih menggunakan model pembelajaran ceramah tanya jawab dan diskusi dalam penyampaian materi kepada santri dengan menggunakan reverensi buku yaitu kitab Bulughul Maram."25

Peneliti dapat menyimpulkan bahawa penyajian informasi ini perlu mempersiapkan atau menyajikan secara matang untuk pelajaran yang akan disampaikan kepada santri. Tidak hanya penyajian informasi tetapi didalam komunikasi juga terdapat merangsang diskusi.

Adapun Iskandar menyatakan bahwa:

"Metode Diskusi cukup efektif terhadap keterampilan mengajar kepada santri, karena metode ini dapat merangsang santri untuk lebih kreatif dalam memberikan gagasan dan ide, serta bertukar pikiran terhadap masalah yang dihadapi dan juga dapat memperkaya pengetahuan, sikap, serta keterampilan yang diperlukan saat proses pembelajaran. Apalagi dalam proses pembelajaran kitab Bulughul Maram materi tentang silaturrahmi ini perlu adanya diskusi yang baik". ${ }^{26}$

Peneliti menganalisis bahwa, meskipun dengan rangsangan diskusi cukup efektif terhadap keterampilan santri dalam proses pembelajaran ternyata ditemukan beberapa masalah dari penerapan rangsangan diskusi tersebut antara lain: memerlukan waktu yang cukup panjang untuk mencari solusi atas

\footnotetext{
${ }^{21}$ Wawancara langsung dengan Ustaz Iskandar, Tanggal 6 November 2019, di Pesantren Nurul Falah Air Mesu Timur. ${ }^{22}$ Observasi, Pelaksanaan Pembelajaran di Pondok Pesantren Nurul Falah Air Mesu Timur 30 Oktober 2019.

${ }^{23}$ Wawancara langsung dengan Ustaz Iskandar, Tanggal 6 November 2019, di Pesantren Nurul Falah Air Mesu Timur. ${ }^{24}$ Wawancara langsung dengan Ustaz Iskandar, Tanggal 6 November 2019, di Pesantren Nurul Falah Air Mesu Timur.

${ }^{25}$ Wawancara langsung dengan Ustaz Iskandar, Tanggal 6 November 2019, di Pesantren Nurul Falah Air Mesu Timur.

${ }^{26}$ Wawancara langsung dengan Ustaz Iskandar, Tanggal 6 November 2019, di Pesantren Nurul Falah Air Mesu Timur.
} 
masalah yang dihadapi, apa lagi belajar tentang kitab Bulughul Maram. Adapun mengarahkan kegiatan siswa juga merupakan salah satu manfaat komunikasi.

Iskandar menyampaikan bahwa:

"seorang ustaz merupakan seseorang yang bertugas menyelenggarakan kegiatan belajar mengajar, membimbing, melatih, mengelola dan serta memberikan pelayanan teknik. Karena seorang ustaz memiliki tugas pokok melaksanakan proses belajar mengajar. Oleh karena itu setiap ustaz harus memiliki kebijakan dan kepribadian yang baik". ${ }^{27}$

Peneliti menganalisis bahwa, mengarahkan kegiatan siswa ustaz haruslah memberikan perlakuan yang baik dan menjurus sesuai dengan bakat, minat dan kemampuan santrinya, ustaz juga menjadi fasilator belajar untuk santrinya, dan intinya ustaz harus profesional dalam melakukan proses belajar mengajar, agar terjalin suatu pembelajaran yang efektif dan efesien, serta menjadi ustaz yang disenangi oleh santrinya. Apa lagi dalam proses pembelajaran kitab Bulughul Maram termasuk pelajaran yang sedikit sulit untuk dipahami oleh para santri. Selain dari mengarahkan kegiatan siswa ada juga manfaat tentang menguatkan belajar.

Iskandar menyatakan bahwa:

"Penguatan belajar sama halnya dengan motivasi yaitu, ditentukan oleh tingkat kemampuan dan keinginan seseorang. Semakin tinggi keinginan seseorang maka akan semakin besar keinginannya untuk belajar".28

Peneliti dapat menyimpulkan bahwa penguatan belajar ini yaitu segala bentuk respon yang merupakan bagian dari modifikasi tingkah laku ustaz terhadap santrinya, yang bertujuan untuk memberikan informasi atau umpan balik bagi santri atas perbuatan atau responnya yang diberikan sebagai suatu dorongan atau koreksi.

\section{KESIMPULAN}

Dari uraian tentang pola komunikasi ustaz dan santri dalam proses pembelajaran kitab bulughul maram materi tentang silaturahmi di Pondok Pesantren Nurul Falah Air Mesu Timur dapat disimpulkan sebagai berikut:

1. Pola komunikasi yang telah digunakan ustaz dalam Pondok Pesantren Nurul Falah terhadap santrinya dalam proses pembelajaran kitab Bulughul Maram dari materi tentang silaturahmi ustaz menggunakan pola komunikasi intruksional yang merupakan komunikasi secara langsung dengan menggunakan lisan seperti menginstruksikan santri membaca hadits dalam kitab bulughul maram materi tentang silaturahmi, dan kemudian menggunakan komunikasi antar pribadi (intrapersonal) misalnya santri berkonsultasi pada ustaz tentang materi pengajian kitab yang dipelajarinya. Dan komunikasi kelompok kecil (Interpersonal) yang dimana sejumlah santri-santri yang terlibat antara yang satu dengan yang lainnya dalam satu pertemuan yang bersifat langsung atau tatap muka

2. Manfaat pola komunikasi ustaz dan santri dalam proses pembelajaran sangatlah penting dalam proses belajar mengajar apalagi dalam pelajaran kitab Bulughul Maram materi tenmtang silaturahmi ini, dan juga membantu ustaz dan santri memudahkan dalam proses belajar mengajar.

\section{REFERENSI}

Mujamil, Qomar, Pesantren Dari Transformasi Metodologi Menuju Demokratisasi Intitusi, Jakarta, Erlangga: tt.

Dhofier Zamakhsyari, 1982. Tradisi Pesantren: Studi Tentang Pandangan Hidup Kyai, Jakarta: LP3S.

Haedari Amin, dkk, 2004. Masa Depan Pesantren: Dalam Tantangan Modernitas dan Tantangan Kompleksitas Globa, Jakarta: IRD Press.

Arifin. 2003. Ilmu Pendidikan Islam. Jakarta: Bumi Aksara

Arikunto, Suharsimi. 2006. Prosedur Penelitian Suatu Pendekaan Praktik. Jakarta: PT.Rineka Cipta

Darmaningtyas. 2005. Pendidikan Rusak-Rusakan. Yogjakarta: PTLkis Pelangi aksara

Hasan, M. Iqbal. 2002. Pokok-Pokok Materi: Metodologi penelitian dan Aplikasinya. Jakarta: Ghalia Indonesia

J Moleong, Lexy. 2000. Metodologi Kualitatif. Bandung: PT Remaja Rosdakarya

\footnotetext{
27 Wawancara langsung dengan Ustaz Iskandar, Tanggal 6 November 2019, di Pesantren Nurul Falah Air Mesu Timur.
}

${ }^{28}$ Wawancara langsung dengan Ustaz Iskandar, Tanggal 6 November 2019, di Pesantren Nurul Falah Air Mesu Timur. 
Paturrohman, Pupuh. 2007. Strategi Belajar Mengajar. Bandung: PT Refika Aditama

Rusyan, Tabrani. 1989. Pendekatan dalam Proses Belajar Mengajar. Bandung: Remaja Rosdakarya Subagio, Jogo. 2003. Metode Penelitian. Jakarta: Rineka Cipta

Sugiyono. 2007. Metodologi penelitian Pendidikan. Bandung: Alfabeta

Sukardi. 2009. Metodologi Penelitian Pendidikan: Kompetensi dan Praktiknya. Jakarta: Bumi Aksara

Tanzeh, Ahmad. 2009. Pengantar Metode Penelitian. Yogyakarta: Teras, 2009 